\title{
Metaphor in Political Media Discourse: Mental Political Leader Portrait
}

\section{Tatyana Yu. Tameryan}

Faculty of Foreign Languages, North-Ossetian State University n. a. K.L. Khetagurov, Vladikavkaz, RUSSIA

(i) 0000-0003-0532-2538 L-1756-2018

\section{Marina R. Zheltukhina}

Institute of Foreign Languages, Volgograd State Socio-Pedagogical University, Volgograd, RUSSIA (D) 0000-0001-7680-4003 Sc 56669701900 A-7301-2015

Đzzmr@mail.ru

\section{Gennady G. Slyshkin}

Institute of Law, Russian University of Transport (MIIT), Moscow, RUSSIA

(i) 0000-0001-8121-0250 SC 57191286505 G-1470-2014

\section{Olga B. Abakumova}

Institute of Foreign Languages, Orel State University named after I.S. Turgenev, Orel, RUSSIA

(iD) 0000-0001-9488-1440 D C-5074-2018

\section{Nadezhda N. Volskaya}

Faculty of Journalism, M.V. Lomonosov Moscow State University, Moscow, RUSSIA

(iD) 0000-0003-0163-3662 D V-7452-2018

\section{Anastasia V. Nikolaeva}

Faculty of Journalism, M.V. Lomonosov Moscow State University, Moscow, RUSSIA

(iD) 0000-0003-1531-681X V V-7343-2018

ARTICLE INFO

Received: 19 July 2018

Accepted: 9 October 2018

Published: 12 November 2018

DOI: https://doi.org/10.12973/ojcmt/3958

ABSTRACT

In the article, we realize the aim of the study. We identify the role of metaphor in the political media discourse as an important part of the mental political portrait. The paper deals with the analysis of Chancellor's metaphoric image structured by the expansion onto the source domain of professional activity, based on simple and compound models and their varieties. The complex methods of cognitive and pragmatic analysis of the mental political leader portrait are used. The article describes the pragmatic power of professional metaphoric models defined by the constant conceptual vectors of ruin and destruction and conceptual vector of protectionism. The ways of analysis are useful for development of communication theory, cognitive linguistics, socio- and psycholinguistics, linguapragmatics, cultural, media, and virtual linguistics. In the article, we establish that the political portrait of the German leader is formed by metaphorical expansions onto various areas of professional activity: law, pedagogics, theatre, circus, fine arts, building, transport (railway), medicine, service, law enforcement, music, hunting. On the material taken simple and composite (double-projected) metaphoric models have been identified. The complex metaphoric unity defines the genre peculiarities and the stylistics. The 
pragmatic power of professional metaphoric models is defined by constant conceptual vector of ruin and destruction.

Keywords: political media communication, political media discourse, concept, picture of the world, cognitive metaphor, metaphorical models, mental political leader portrait, media image design

\section{INTRODUCTION}

Political linguistics as a special branch of science focuses attention on the domestic and foreign policy discourses along with political figures images. T. van Deijk correlates the notion of political discourse with the types of genre determined by the political sphere. He involves the description of such genre variations as government discussions, parliamentary debates, party programs and speeches of politicians (Dijk, 1989). However, the latest trends of political linguistics development are aimed at political communication study of diverse contexts and genres (Petrenko \& Potapova, 2014; Franssila, 2013).

The aim of the study is to identify the role of metaphor in the political media discourse as an important part of the mental political portrait. The overarching research question of this study was as follows: how can we identify the role of metaphor in the political media discourse as an important part of the mental political portrait? For realization of our research aim we will consider a mental political portrait of the leader on the example of the German Chancellor Angela Merkel.

\section{LITERATURE REVIEW}

The research of metaphorization process as a way of thinking and reasoning tool in political communication is based on understanding a metaphor as a means of description of the political picture of the world. Interaction is an important part of making politics. According to T. van Dijk (1997), the public sphere of politics is accomplished in the form of speech, which ranges from controversy and revelations to proclamation and declaration.

Political metaphor study is undertaken by the Russian and foreign scientists. Review of publications on the subject of metaphor in political media discourse (Aleshchanova et al., 2017; Beard, 2000; Chilton, 2004; Chudinov, 2006; Dijk, 1989; Fetzer, 2007; Franssila, 2013; Gulinov et al., 2018; Obeng, 1997; Petrenko, \& Potapova, 2014; Ponomarenko et al., 2018; Sausheva, 2017; Slyshkin 2007; Tameryan, 2015a; 2015b; Tameryan, \& Tsagolova, 2013; 2015; Tameryan et al., 2018, Wilson, 1990; Volskaya et al., 2017; 2018; etc.) showed that works of domestic and foreign linguists in the field of comparative linguistics, socioand psycholinguistics, pragmalinguistics, cognitive linguistics, cultural linguistics, stylistics, rhetoric, of the theories of discourse and influence have formed theoretical base of the research.

In our research we use the complex methods of cognitive and pragmatic analysis of the mental political leader portrait. The ways of analysis are useful for development of communication theory, cognitive linguistics, socio- and psycholinguistics, linguapragmatics, cultural, media, and virtual linguistics. The article describes the pragmatic power of professional metaphoric models defined by the constant conceptual vectors of ruin and destruction and conceptual vector of protectionism.

\section{RESULTS AND DISCUSSION}

The description of A. Merkel's personal discourse along with the analysis of her language personality is at present at the primary level of research. 
The material for this study is based on texts from the German news and political journals "Der Spiegel" and "Focus".

In this article the metaphorical layer of the concept of sociopolitical and personal type Kanzlerin Angela Merkel and it value component are described (Tameryan, \& Tsagolova $2013 ; 2015)$. But the problem of differentiation of metaphorical layer of a concept is not developed enough (Tameryan, 2015b).

Metaphors in the structure of the concept Kanzlerin Angela Merkel serve to reveal the basic mechanism of explanation and evaluation of the political leader's activity to mass readers.

The analysis of metaphor constituent of political communication involves study of each text fragment with regard to the political situation in which it was created, its intertextual links, intentions and ideological positions of publishing houses (Chudinov, 2006; 86).

The process of enrichment of political metaphorics is described on the material of Kanzlerin Angela Merkel's metaphoric image, which covers the domain of professional associations constituting the image of the German Chancellor (Tameryan, \& Tsagolova, 2013).

Professional metaphors characterizing A. Merkel in analytical and news issues of the German mass media are widely used. The political portrait of the German leader is formed by metaphorical expansions onto various areas of professional activity:

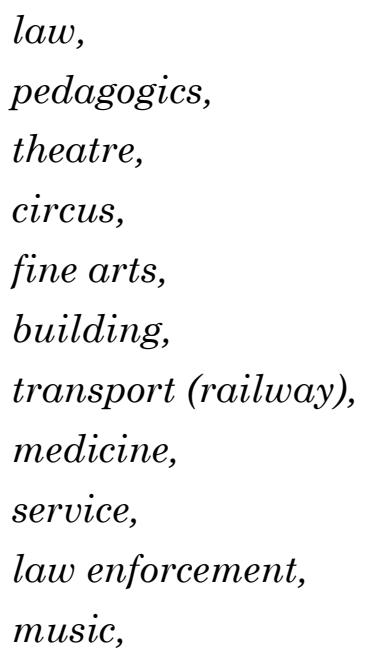

hunting.

The metaphoric model Angela Merkel is Gouvernante vom Dienst as well as other models of the pedagogic metaphorics imply both low evaluation of Chancellor's political strategies and narrowness of their usage:

$<\ldots$.. Und Angela Merkel, die Kanzlerin der Bundesrepublik Deutschland, wurde da oft genug zur Gouvernante vom Dienst (Ackeren, 2011).

In this manner the journal "Focus" creates the image of Angela Merkel as an inactive, ideologically short-sighted leader, incapable to guide the actions of ruling coalition and opposition.

In the metaphoric arsenal of the concept Kanzlerin Angela Merkel the metaphor of pedagogics marks gender identity in the professional activity, emphasizing the idea of the Chancellor of Germany being a woman.

The composite model Angela Merkel is die gnadenlose teutonische Zuchtmeisterin "cruel Teutonic teacher" is formed by the basic projection onto the 
domain of pedagogics (component Zuchtmeisterin "teacher") and the additive one in the field of German history (component gnadenlose teutonische "cruel Teutonic"), dated back to the Teutonic Order the members of which were known for their cruelty to their enemy, but kindness for those who were their subordinate (an allusion for Chancellor's patronage of her retinue).

The metaphors from the source domain of law form meanings connected with right regulations for citizens, legal entities and organizations. A. Merkel as a state leader should ensure compliance with the law and freedoms. However, the image of Chancellor upholding the law only for the rich in her country has been formed in German mass media discourse.

Synonymous models which will be discussed below present to readers' mind one-sided social care about the citizens of the country.

For example, the metaphoric model Angela Merkel is oberste Friedensrichterin (der Koalition) represents two-vector expansion, where the dominant vector aims to the law domain, and the additive one refers to the status area:

Friedensrichterin (der Koalition) «judge (of coalition)» and oberste "supreme, high».

The pragmatic power of the model is lowered due to the metaphoric sense of destruction - the lack of leader's qualities needed for political managment and fighting - imparts the metaphor oberste Friedensrichterin (der Koalition) "supreme judge (of coalition)» connotations of sarcasm.

The metaphor of ruin and destruction describes the state of affairs in the party contrary to the situation of Margaret Thatcher's popularity during her first years in prime minister's office.

The service metaphor which is based on the models Angela Merkel is Reinigungskraft and Angela Merkel is Sauberfrau explicits the image of the lowest qualification worker indicating the unpretentiousness of Chancellor's strategies and tactics (Tameryan, 2015b):

<...> Beide traten ihren Job als Trümmerfrauen und Reinigungskräfte an - weil die Männer zu feige für den Job waren (Augstein, 2012).

The medical metaphor Angela Merkel is die Krankenpflegerin (des Euro) also evaluates A. Merkel's management at the level of an average professional qualification as the leader of the FRG is shown not as a doctor but as a nurse of Euro (die Krankenpflegerin des Euro):

<...> Merkel ist die Krankenpflegerin des Euro, an der Spitze eines der einflussreichsten Länder der EU (Sontheimer, 2013).

Gender-marked hunting metaphor based on the model Angela Merkel is die geduldige Jägerin, conveys the female principle of holding political talks with male politicians.

The metaphoric projection onto the domain of construction work does not only structure the image of A. Merkel according to the model Angela MerkI is die Sprengmeisterin, but also forms the scenario of preliminary stage of construction work, that is clearing of land.

Old Europe is shown as a shabby habitation (marodes Haus) which needs to be destroyed. The observers and helpers of the explosion work are the EU countries being sure that they are on a safe side (eine kontrollierte Sprengung), because they are 
protected by helmets (Helme) and shafts (Schutzwälle), while A. Merkel is working as a shot firer who pushes the button (initiation metaphor).

As one can see the theme of ruin, destruction and clearing is raised again introduced by metaphors of explosion and ruin (of Europe) (Tameryan, 2015b):

Merkel hat die Sprengung eines sehr maroden Hauses vorbereitet. Sie hat dem Druck widerstanden, sofort auf den Auslöser zu drücken. Nun gibt es eine kontrollierte Sprengung: Alle Umstehenden haben wenigstens Helme auf, und es gibt Schutzwälle, die die Trümmer abfangen können (Nelles, 2011).

The projection onto the conceptual domain of law enforcement functioning and the additive sphere of status hierarchy according to the models Angela Merkel is Frau Komissar and Angela Merkel is böse deutsche Sparkommissarin reflects A. Merkel's initiatives providing strict budget policy and coordination of economical politics in the EU countries in order to diminish state debt and its negative evaluation.

The circus metaphor Angela Merkel is Akrobat draws the situation of illusory activity and sleight of A. Merkel in the process of plugging the gap on the political stage:

Wie ein Akrobat, der zehn Teller gleichzeitig in der Luft halten muss, eilt Merkel von einer Gefahrenstelle zur nächsten (Ackeren, \& Pörtner, 2009).

The projection onto the conceptual domain of law enforcement functioning and the additive sphere of status hierarchy according to the models Angela Merkel is Frau Komissar and Angela Merkel is böse deutsche Sparkommissarin reflects A. Merkel's initiatives providing strict budget policy and coordination of economical politics in the EU countries in order to diminish state debt and its negative evaluation.

We revealed various kinds of metaphors:

- metaphors of game

hat Farbe bekannt (openly said about her intentions),

- metaphors of war

den Gegner attackiert (attacked her enemy that is her opposition),

- metaphors of colour

- Schwarze unter Schwarzen («black among black», the color symbol of CDU party),

- Internet metaphors

Moderatorin (moderator)

- theatre metaphors

Regisseurin (director, regisseur).

These metaphors describe the complex A. Merkel's political strategy to settle various conflicts between political parties.

The graduated model Angela Merkel is Moderatorin - Angela Merkel is die Regisseurin indicates the increasing ability of A. Merkel not only to observe or moderate the situation but to direct her own plays at political theatre in the spirit of the old theater that reject modernity and innovation.

Thus, the study described above shows that the metaphoric field fragment representing the concept Kanzlerin Angela Merkel is formed by expansion onto the source domain of professional activity, structured by 17 types of metaphors and 23 their variations.

On the material taken simple and composite (double-projected) metaphoric models have been identified. Their dominant source domain refers to professional activity (the 
field of law, the sphere of pedagogics, the field of musical art), and the additive ones are connected with the status and position hierarchy, the German history and the international relations.

The complex metaphoric unity defines the genre peculiarities and the stylistics of the following fragment:

Merkel hat also gemacht, was viele Parteifreunde von ihr wollten. Sie hat Farbe bekannt, den Gegner attackiert, ist - so empfinden es viele Parteifreunde im Südwesten - endlich zur Schwarzen unter Schwarzen geworden. <...> Mit der Merkel-Mutation von der zögernden Moderatorin zur Regisseurin mit Blick fürs Konservative ist sie der Abhängigkeit vom Erfolg im Südwesten entkommen. Die Union steht zusammen, gewinnt-oder verliert - gemeinsam (Ackeren, 2010).

The metaphors indentified characterize the following cognitive features in the structure of the concept Kanzlerin Angela Merkel:

1) home politicy - political parties leadership; internal political management; social protectionalism of Chancellor; attitude towards her subordinates;

2) foreign political activity of Chancellor - the part of A. Merkel in the EU; A. Merkel's activity in regulating economic situation in Europe and the world; foreign political management.

\section{CONCLUSION}

So we come to the conclusion that professional metaphor negatively marks A. Merkel's political management and her qualities as Chancellor, socially oriented protectionalism, her policy aimed at the countries in crisis. A. Merkel's role in the EU is evaluated contradictory.

The principles and the ways of A. Merkel conducting negotiations with male politicians and her part in the EU formation are positively marked.

Feminine marked models connect the image of A. Merkel with typically female professions: die Zuchtmeisterin, Gouvernante, Reinigungskraft, Sauberfrau, die Krankenpflegerin which proves the low professional estimation of A. Merkel as a state leader.

The pragmatic power of professional metaphoric models is defined by constant conceptual vector of ruin and destruction which characterizes the strife between political parties within the coalition and the leading CDU party; the instability of the internal political strategic course of the FRG; the destruction of the status quo in Europe; instable economical situation in the EU; economical collapse in a number of Southern European countries.

Merkel's leadership is characterised through the vector of irreality described by the dominant models formed by the expansions onto the domains of circus, theatre and music.

\section{REFERENCES}

Ackeren, M. (2011). Hat sich Angela Merkel den Urlaub verdient? In: FOCUS Magazin, Nr. 30. 25.07.2011. Retrieved from https://www.focus.de/politik/deutschland/politikhat-sich-angela-merkel-den-urlaub-verdient_aid_648633.html

Ackeren, M. van, \& Pörtner, R. (2009). Säbel gegen Florett. In: FOCUS Magazin, Nr. 13. 23.03.2009. Retrieved from https://www.focus.de/politik/deutschland/union-saebelgegen-florett_aid_382737.html 
Online Journal of Communication and Media Technologies, 2018

Ackeren, M. van. (2010). Wahlkrimi 2011. Was blüht der Kanzlerin im Wahljahr 2011? In: FOCUS Magazin, Nr. 52. 27.12.2010. Retrieved from https://www.focus.de/magazin/archiv/wahlkrimi-2011-was-blueht-der-kanzlerin-imwahljahr-2011_aid_584891.html

Aleshchanova, I. V., Frolova, N. A., Morozova, E. V., \& Zheltukhina, M. R. (2017). Psychological and Acmeological Aspect of Educational Cognitive Competence Development. In: Proceedings of the 7th International Scientific and Practical Conference Current Issues of Linguistics and Didactics: The Interdisciplinary Approach in Humanities (CILDIAH 2017). Advances in Social Science, Education and Humanities Research (ASSEHR), 97, 19-24. https://doi.org/10.2991/cildiah-17.2017.4

Augstein, J. (2012). S.P.O.N. - Im Zweifel links: Margaret Merkel? So ein Quatsch! In: Spiegel online. 01.03.2012. Retrieved from http://www.spiegel.de/politik/deutschland /s-p-o-n-im-zweifel-links-margaret-merkel-so-ein-quatsch-a-818554.html

Beard, A. (2000). Language of Politics. London: Routledge.

Chilton, P. (2004). Analysing Political Discourse: Theory and Practice. NewYork: Routledge. https://doi.org/10.4324/9780203561218

Chudinov, A. P. (2006). Political Linguistics: Moscow: Flinta: Science.

Dijk, van T. (1997). Discourse as Structure and Process: Discourse Studies a Multidisciplinary Introduction. L.: SAGE Publication Ltd.

Dijk, van T. A. (1989). Language. Cognition. Communication. Moscow: Progress.

Fetzer, A. (2007). Political Discourse in the Media. Amsterdam: John Benjamins Publishing Co. https://doi.org/10.1075/pbns.160

Franssila, S. (2013). Sell Metaphor in American Political News Discourse. In: Social and Behavioral Sciences, 95, 418-424. https://doi.org/10.1016/j.sbspro.2013.10.664

Gulinov, D. Yu., Zheltukhina, M. R., Shestak, L. A., Slyshkin, G. G., Katermina, V. V., \& Chervyakova, L. D. (2018). Modern Language Policy: Specifics of Formation and Development of the French Vertical. Modern Journal of Language Teaching Methods, 8(2), 159-173.

Nelles, R. (2011). Euro-Krise. Die Sprengmeisterin. In: Spiegel online. 27.10.2011. Retrieved from http://www.spiegel.de/politik/deutschland/euro-krise-diesprengmeisterin-a-794314.html

Obeng, S. G. (1997). Language and Politics: Indirectness in Political Discourse. Discourse \& Society, 8(1), 49-83. https://doi.org/10.1177/0957926597008001004

Petrenko, V. V., \& Potapova A. S. (2014). Political Linguistics as a Constituent Part of Modern Political Theory. In: Social and Behavioral Sciences, 154, 482-485. https://doi.org/10.1016/j.sbspro.2014.10.197

Ponomarenko, E. B., Vasilkova, N. N., Volskaya N. N., Kasperova, L. T., \& Nikolaeva, A. V. (2018). Female political media discourse in American and English linguocultures: speech strategies and tactics. XLinguae, 11(2), 625-638. https://doi.org/10.18355/XL.2018.11.02.50

Sausheva, E. V. (2017). Metaphor role in communicative process. Bulletin of the Kostroma State University, 4(23), 234-235.

Slyshkin, G. G. (2007). Concept of personality as element of linguocultural historical sphere (on material of the concept "Talleyrand"). Ethnohermeneutik und kognitive Linguistik / Hrsg. von R.D. Kerimov. Landau: Verlag Empirische Pädagogik, 81-88.

Sontheimer, M. (2013). Regierungschefinnen Was Merkel von Thatcher unterscheidet. In: Spiegel online. 08.04.2013. Retrieved from http://www.spiegel.de/politik/ausland/ historischer-vergleich-von-margaret-thatcher-und-angela-merkel-a-893208.html 
Tameryan, T. Yu, \& Tsygalova, V. A. (2013). Nominative Field of the Social and Cultural concept Kanzlerin Angela Merkel - Chancellor Angela Merkel. In: Political Linguistics, 4, 151-155.

Tameryan, T. Yu. (2015b). Allusions in Contemporary Political Discourse. Cognitive Study of Language, 22, 409-411.

Tameryan, T. Yu. (2015a). Chancellor of Germany in the Metaphorical Mirror of Political Discourse. Issues of Cognitive Linguistics, 4, 81-87.

Tameryan, T. Yu., \& Tsagolova, V. A. (2015). Oppositive Metaphorical Models in the German Political Discourse. In: Russian Linguistic Bulletin, 2(6), 22-23.

Tameryan, T. Yu., Zheltukhina, M. R., Slyshkin, G. G., Shevchenko, A. V., Katermina, V. V., \& Sausheva, Ye. V. (2018). New Country's Political Discourse: Formation of Speech Technologies. Modern Journal of Language Teaching Methods, 8(7), 151-160.

Volskaya, N. N., Borbotko, L. A., Zheltukhina, M. R., Kupriyanova, M. E., \& Ilina, A. Yu. (2017). Effective Suggestive Psychotechniques in the Political Media Discourse. XLinguae Journal, 10(4), 84-95. https://doi.org/10.18355/XL.2017.10.04.08

Volskaya, N. N., Tameryan, T. Yu., Zheltukhina, M. R., Boeva-Omelechko, N. B., Komleva, L. A., \& Knyazeva, Ye. G. (2018). Literary Translation as Cognitive Overlap between Foreign and Native Languages. Modern Journal of Language Teaching Methods, 8(7), 161-172.

Wilson, G. D. (1990). Ideology and Humor Preferences. International Political Science Review, 11(4), 461-472. https://doi.org/10.1177/019251219001100404

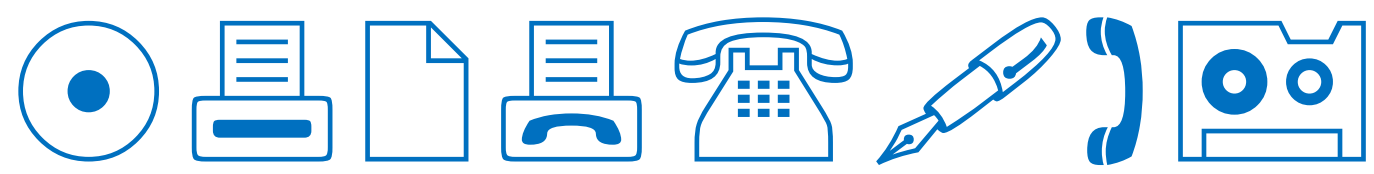

